\title{
SPRAWOZDANIE Z KONFERENCJI „AKTUALNE PROBLEMY PRAWA GOSPODAROWANIA ODPADAMI", KATOWICE, DNIA 5 MAJA 2015 ROKU
}

\section{THE REPORT ON THE CONFERENCE "CURRENT PROBLEMS OF WASTE MANAGEMENT LAW", KATOWICE, $5^{\mathrm{TH}}$ MAY 2015}

\section{STRESZCZENIE}

5 maja 2015 r. na Wydziale Prawa i Administracji Uniwersytetu Śląskiego w Katowicach odbyła się ogólnopolska konferencja nauko-

* Magister prawa, asystent w Katedrze Prawa Górniczego i Ochrony Środowiska na Wydziale Prawa i Administracji Uniwersytetu Śląskiego w Katowicach.

" Student, członek Koła Naukowego Prawa Ochrony Środowiska na Wydziale Prawa i Administracji Uniwersytetu Śląskiego w Katowicach. 
wa „Aktualne problemy prawa gospodarowania odpadami”. Jej celem było zwrócenie uwagi na aktualne problemy w stosowaniu przepisów dotyczących gospodarowania odpadami - zwłaszcza przemysłowymi, przy uwzględnieniu, stanowiących tło tych regulacji, konkretnych wymogów technologii i ochrony środowiska.

\section{Słowa kluczowe}

Prawo ochrony środowiska; gospodarka odpadami.

\section{ABSTRACT}

On 5th May 2015 at the Faculty of Law and Administration at the University of Silesia in Katowice a nationwide conference on "Current problems of waste management law", organized by the Students' Scientific Association of the Environmental Law at the Faculty of Law and Administration at the University of Silesia, was held. The aim of the conference was to draw attention to current problems in applying waste management regulations while taking into account specific requirements of technology and law protection, which constitute their background.

\section{Keywords}

Environmental law; waste management.

5 maja 2015 r. na Wydziale Prawa i Administracji Uniwersytetu Śląskiego w Katowicach odbyła się ogólnopolska konferencja naukowa pt. „Aktualne problemy prawa gospodarowania odpadami" zorganizowana przez Koło Naukowe Prawa Ochrony Środowiska WPiA UŚ oraz Katedrę Prawa Górniczego i Ochrony Środowiska WPiA UŚ. Wydarzenie zostało objęte patronatem honorowym Dziekana Wydziału Prawa i Administracji Uniwersytetu Śląskiego - prof. dr hab. Czesława Martysza oraz Polskiej Izby Ekologii.

Celem konferencji było zwrócenie uwagi na problemy w stosowaniu przepisów dotyczących gospodarowania odpadami - zwłaszcza przemysłowymi - przy uwzględnieniu, stanowiących tło tych regulacji, konkretnych wymogów technologii 
i ochrony środowiska. Zorganizowanie opisywanego wydarzenia było wynikiem dostrzeżenia żywotności wskazanej materii nieustannie zasilanej nowymi normami. Był to także wyraz uznania dla ogromnej i wciąż rosnącej praktycznej roli prawa gospodarowania odpadami.

Spotkanie zgromadziło kilkudziesięciu uczestników, wśród których znaleźli się m.in.: pracownicy naukowi, przedstawiciele organów administracji publicznej (w tym naczelnicy wydziałów środowiskowych z Katowic, Piekar Śląskich i Mikołowa, przedstawiciele Urzędu Marszałkowskiego Województwa Śląskiego czy Wojewódzkiego Inspektoratu Ochrony Środowiska w Katowicach), reprezentanci przedsiębiorców, a także doktoranci i studenci tutejszego wydziału. Goście wydarzenia otrzymali publikację pt. Prawna regulacja geologii i górnictwa $w$ Polsce, Czechach i na Stowacji. Wybrane zagadnienia (red. G. Dobrowolski, G. Radecki), będącą owocem XIV polsko-czesko-słowackiej konferencji Prawne zasady ochrony środowiska w związku z gospodarowaniem jego geologicznymi zasobami, która odbyła się w dniach 11-13 września 2013 r. w Kroczycach.

Konferencję uroczyście otworzył opiekun Koła Naukowego POŚ WPiA UŚ - dr hab. Grzegorz Dobrowolski. W swoim wystąpieniu zwracał uwagę zgromadzonych - szczególnie studentów - na znaczenie prawa ochrony środowiska i zachęcał ich do bliższego zainteresowania się tymi normami. Wśród prelegentów znaleźli się przedstawiciele Uniwersytetu Jagiellońskiego, Uniwersytetu Kazimierza Wielkiego w Bydgoszczy, Uniwersytetu Łódzkiego oraz Uniwersytetu Śląskiego w Katowicach (w tym również członkowie Koła Naukowego Prawa Ochrony Środowiska WPiA UŚ). Wydarzenie podzielone zostało na trzy panele, podczas których przedstawiono jedenaście referatów:

- System planowania gospodarki odpadami $w$ Polsce (dr hab. Zbigniew Bukowski, prof. UKW);

- Zasady prawa gospodarki odpadami (Klaudia Cholewa, Katarzyna Zawada, UŚ);

- Odpad a produkt uboczny $w$ świetle prawa (Wojciech Iskra, UŚ);

- Problem egzekucji opłat za gospodarowanie odpadami (mgr Kamil Miśtal, UŁ); 
- Prawne i techniczne aspekty gospodarowania odpadami medycznymi i weterynaryjnymi (Katarzyna Pietrzak, UŁ);

- Prawne zasady postępowania ze zwłokami zwierzęcymi i ich częściami (mgr Justyna Więcławek, UŚ);

- Obowiąki gmin $w$ zakresie gospodarowania odpadami (Alina Prochasek, Martyna Ścierska, UŚ);

- Narastajace kontrowersje wokót RIPOK (Magdalena Chmielarz, UŚ);

- Paliwo alternatywne - zagadnienia prawne (mgr Lech Dubiński, UJ);

- Gospodarowanie odpadami opakowaniowymi w świetle przepisów Ustawy o opakowaniach i odpadach opakowaniowych (r.pr. Ewa Badowska-Domagała);

- Charakter prawny porozumienia zawieranego na podstawie art. 25 Ustawy z dnia 13 czerwca 2013 r. o gospodarce opakowaniami i odpadami opakowaniowymi (mgr Oskar Możdżyń, UŚ).

Po każdym z paneli pomiędzy uczestnikami toczyła się żywa i intensywna dyskusja dotycząca kwestii problematycznych, jakie zostały zasygnalizowane $\mathrm{w}$ trakcie wystąpień prelegentów. Biorący udział w dyskusji wskazywali na szereg wątpliwości związanych z gospodarowaniem odpadami, mających swe źródło w głównej mierze $\mathrm{z}$ niejasności przepisów regulujących omawiane zagadnienia, wynikającej często z szybkości prac legislacyjnych, która z kolei przekłada się na jakość norm prawa w tej dziedzinie. Do najciekawszych wątków tej części konferencji należały rozważania na temat właściwego odczytania zasady bliskości w odniesieniu do odpadów medycznych, spór o odpowiedni model egzekucji opłat za gospodarowanie odpadami, głosy dotyczące wielkiej niefrasobliwości władz lokalnych w podejściu do problemu postępowania ze zwłokami zwierząt domowych czy refleksje na temat przyczyn takiego, a nie innego ukształtowania instytucji porozumienia z art. 25 Ustawy o gospodarce opakowaniami. Nie zabrakło też zwrócenia uwagi na patologie polskiego systemu gospodarowania odpadami, jak i bardzo daleko idącej konkluzji, że system ten będzie funkcjonował źle dopóki jego charakter nie zmieni się 2/2015 z nakazowo-rozdzielczego na wolnorynkowy. 
Na zakończenie głos zabrał prof. dr hab. Aleksander Lipiński, który w swoich słowach podkreślił szczególne znaczenie szeroko rozumianego prawa ochrony środowiska nie tylko w polskim porządku prawnym, ale także w życiu codziennym. Zaakcentował, że stosowaniem tych norm najczęściej zajmują się nie prawnicy - specjaliści z tej dziedziny, co często skutkuje jurydyczną wadliwością ich rozstrzygnięć. Jednocześnie Profesor - podobnie jak na wstępie dr hab. Grzegorz Dobrowolski - zachęcał obecnych na auli studentów do zainteresowania się wspomnianą gałęzią prawa. Można zresztą w tym miejscu zauważyć, że prawo ochrony środowiska to wspaniałe pole badawcze nie tylko dla miłośników prawa administracyjnego, karnego czy cywilnego, ale również innych dyscyplin prawniczych. Potwierdzeniem tej tezy może być niezwykle ciekawe wystąpienie pt. Prawne zasady postępowania ze zwłokami zwierzęcymi i ich czesściami, zaprezentowane podczas konferencji przez mgr Justynę Więcławek z Katedry Teorii i Filozofii Prawa UŚ.

Przebieg wydarzenia skłania do optymizmu. Była to pierwsza konferencja organizowana przez Koło Naukowe Prawa Ochrony Środowiska WPiA UŚ i należy ją ocenić jako ogromny sukces, tak ze względu na poruszaną tematykę, jak i sprawne przygotowanie. Organizatorom należą się wyrazy uznania za niezwykłe zaangażowanie i pasję, z jaką podeszli do postawionego sobie zadania. Duża liczba słuchaczy, dodatkowo aktywnie uczestniczących w toczonych dyskusjach, uprawnia do stwierdzenia, iż konferencja była nie tylko ważnym wydarzeniem naukowym, ale również istotnym instrumentem dla upowszechnienia w Polsce wiedzy na temat gospodarowania odpadami. Bogactwo wystąpień ukazało jak szerokim, interesującym i niezgłębionym dotychczas zagadnieniem badawczym jest problematyka prawa gospodarowania odpadami. Pozostaje mieć nadzieję, że - dzięki inicjatywie i zaangażowaniu młodych - inicjatywa ta będzie kontynuowana w kolejnych latach.

\section{Kontakt e-mail:}

ewa.olejarczyk@us.edu.pl

m.suska@poczta.onet.pl 